DOI: 10.34015/2523-4552.2020.3.10

удк 342.95

Почанська О. С.,

доктор юридичних наук, доцент

кафедри правового забезпечення

господарської діяльності

факультету № 6

Харківського національного

університету внутрішніх справ

ORCID: 0000-0003-3953-8660

\title{
ПОНЯТТЯ, ЗМІСТ ТА ОСНОВНІ ФУНКЦІЇ \\ СУЧАСНИХ МІЖНАРОДНО-ПРАВОВИХ СТАНДАРТІВ \\ У СФЕРІ ЗАБЕЗПЕЧЕННЯ ПРАВ ГРОМАДЯН, ЗАСУДЖЕНИХ ДО ПОЗБАВЛЕННЯ ВОЛІ
}

Визначено зміст поняття міжнародно-правових стандартів у галузі прав людини. Проаналізовано основні сучасні наукові підходи до визначення специфічних особливостей міжнародних стандартів поводження з засудженими. Виділено головні функції сучасних міжнародно-правових стандартів у сфері забезпечення прав громадян, засуджених до позбавлення волі, охарактеризовано їх зміст.

Ключові слова: міжнародно-правові стандарти прав людини; міжнародні стандарти поводження із засудженими; засуджений до позбавлення волі.

Определено содержание понятия международно-правовых стандартов в области прав человека. Проанализированы основные современные научные подходы к определению специфических особенностей международных стандартов обращения с осужденными. Выделены основные функции современных международно-правовых стандартов в сфере обеспечения прав граждан, осужденных к лишению свободы.

Ключевые слова: международно-правовые стандарты прав человека; международные стандарты обращения с осужденными; осужденные к лишению свободы.

Постановка проблеми. Ключовою проблемою процесу вдосконалення забезпечення прав і свобод громадян, засуджених до позбавлення волі в Україні, наразі $є$ адаптація національного законодавства (i, зокрема, його адміністративно-правової складової, яка була й залишається одним із найважливіших чинників забезпечення належного стану суспільних відносин у цій сфері) до сучасних міжнародних стандартів поводження із засудженими, що становлять невід'ємну складову частину загальновизнаних світових стандартів у галузі прав людини.

Аналіз останніх досліджень і публікацій. Міжнародно-правові 
стандарти в галузі прав людини були предметом наукового аналізу таких вітчизняних і зарубіжних учених, як М. Антонович, Ю. Білас, Ю. Грошевий, 0. Лукашева, О. Музичук, П. Рабінович, О. Руднєва, О. Тіунов, Л. Ульяшина, $\quad$ В.Філіппов та ін. Окремі аспекти закріплення міжнародних стандартів поводження 3 засудженими у національному законодавстві України розглядали $€$. Бараш, І. Василюк, М. Гуцуляк, О. Іваньков, С. Клименко, О. Лисодєд, В. Льовочкін, О. Романюк, Н. Рябих, А. Степанюк, В. Човган, I. Яковець, М. Яцишин.

Проте динамічність міжнародно-правових стандартів у галузі прав людини, а також розвиток процесів реформування пенітенціарної системи України та адаптації національного законодавства до загальноєвропейських і світових стандартів у контексті євроінтеграції України актуалізують необхідність перегляду змісту та особливостей міжнародних стандартів у сфері забезпечення прав громадян, засуджених до позбавлення волі.

Постановка завдання. Метою статті $€$ дослідження змісту і особливостей сучасних міжнародноправових стандартів у сфері забезпечення громадян, засуджених до позбавлення волі, що передбачає уточнення поняття міжнародноправових стандартів у галузі прав людини, визначення й характеристику специфічних особливостей міжнародних стандартів щодо забезпечення прав засуджених, окреслення головних функцій міжнародноправових стандартів у сфері забезпечення громадян, засуджених до позбавлення волі, та аналіз їх змісту.
Виклад основного матеріалу. У широкому розумінні міжнародні стандарти у сфері прав людини поєднують весь масив міжнародних нормативних документів, які пройшли процедури обговорення й узгодження на міжнародному рівні та які закріплюють гарантії індивідуальних прав і свобод людини та громадянина. Внаслідок універсальності та значимості для захисту прав і свобод міжнародні стандарти у сфері прав людини визнаються критеріями оцінки виконання міжнародних зобов'язань, незалежно від того, чи $\epsilon$ вони обов'язковими або рекомендаційними за своїми правовими наслідками, чи входять або ні вони до переліку основних джерел міжнародного права. У вузькому розумінні міжнародні стандарти у сфері прав людини являють собою групу міжнародних документів, що не входять до існуючого переліку джерел міжнародного права і являють собою стандартні правила, принципи й рекомендації в галузі безпосереднього виконання або вироблення політики дій щодо певних питань регулювання індивідуальних прав і свобод людини та громадянина [1, с. 28-29].

Отже, міжнародні стандарти визначають обов'язковий або рекомендований для держав нормативний мінімум правового статусу особистості, в тому числі його юридичний захист і відповідні правочинності та обов'язки державних органів й посадових осіб. При цьому, до міжнародних стандартів відносяться не лише права й свободи людини, але й умови, в яких вони реалізуються і які пов'язані з законними обмеженнями та заборонами. Крім того, міжнародним співтовариством виро- 
блено низку стандартів діяльності державних органів щодо забезпечення прав і свобод людини та громадянина. Так, зокрема, у Резолюції Генеральної Асамблеї ООН «Встановлення міжнародних стандартів в галузі прав людини» № 41/120 від 4 грудня 1986 р. зазначено, що стандарти повинні:

- відповідати існуючим нормам міжнародного права;

- мати базовий характер;

- виходити $з$ поняття гідності та цінності людини;

- бути досить чіткими, щоб дати можливість виділити права i обов'язки, які можна реалізувати;

- містити в собі, по можливості, механізм ефективної імплементації, в тому числі й систему звітів;

- привертати увагу й залучати підтримку міжнародного співтовариства [2].

Сучасні науковці визначають такі основні ознаки міжнародних стандартів у галузі прав людини:

1) Фіксованість (міжнародно-правові стандарти фіксують у собі показники) певного змісту та певного обсягу прав і свобод людини. Окрім того, як відзначає П. Рабінович, стандартизуватись можуть також і певні вимоги до засобів гарантування прав людини (зокрема, обов'язки держави із забезпечення, охорони та захисту таких прав) [3, c. 22].

2) Модельність (міжна-родноправові стандарти $\epsilon$ настановами (або формально-обов'язковими, або ж рекомендаційними), які мають братись до уваги і при міжнародноправовому та національному конструюванні усіх інших юридичних норм стосовно прав людини) [4, c. 69].
3) Специфіка санкцій за порушення міжнародних стандартів. Дані санкції можуть мати або політико-юридичний (щодо обов'язкових приписів), або ж суто політичний (щодо рекомендаційних приписів) характер.

4) Універсальність міжнародно-правових стандартів (всесвітня чи регіональна) [3, с. 22].

5) Змістова динамічність (забезпечувана, насамперед, за посередництвом їх офіційної інтерпретації - навіть при незмінності загального текстуального вираження) [5, c. 13].

Аналіз наукових праць у даній сфері дозволяє також визначити низку важливих функцій, які виконують сучасні міжнародні стандарти у галузі прав людини. Зокрема, вони:

-визначають нормативний мінімум або припустимий консенсус для державної регламентації;

-встановлюють критерії оцінки виконання міжнародних зобов'язань;

-відбивають нову етику у взаєминах між членами міжнародного співтовариства, міжнародними інститутами й людиною;

$$
\text { -сприяють зростанню }
$$
міжнародного інтересу до прав людини;

-слугують засобом інформаційного обміну;

-містять рекомендації з формування національної практики забезпечення прав і свобод людини;

-сприяють імплементації міжнародних зобов'язань у даній сфері;

-висувають загальнодемократичні вимоги до держав щодо належного забезпечення прав і свобод людини [6, с.112; 7, с.18; 8, с.156]. 
Л. Ульяшина цілком слушно пропонує об'єднати увесь комплекс функцій міжнародних стандартів у галузі прав людини у такі функції, як:

- нормативна (визначення нормативного мінімуму державної регламентації; вироблення рекомендацій 3 формування національної практики та ін.);

- контрольна ( $\epsilon$ засобом виміру виконання міжнародних зобов'язань та основою для забезпечення консенсусу у державній регламентації та ін.);

- інформаційна ( $\epsilon$ засобом інформаційного обміну; формулюють загальнодемократичні вимоги до державної влади та ін.);

- захисна (сприяють імплементації міжнародних зобов'язань, забезпечують ефективний захист суб'єктів правовідносин у даній сфері та ін.);

- просвітницька (сприяють зростанню міжнародної уваги до прав людини; відбивають нову етику у взаємовідносинах між суб'єктами міжнародного співтовариства, міжнародними інститутами й людиною та ін.) [9, с.78].

У свою чергу, під міжнародними стандартами поводження із засудженими розуміються прийняті на міжнародному рівні норми, принципи і рекомендації у галузі виконання покарань і діяльності органів і установ виконання покарань, в яких сконцентрований світовий досвід та гуманістичні тенденції системи розвитку кримінальних покарань [10, c. $23 ; 11$, c. 64$]$.

у межах єдиної системи міжнародного права уся сукупність юридичних, соціальних, економічних норм захисту прав людини, яка пере- буває в умовах позбавлення волі, складає міжнародно-правовий інститут захисту прав людини, засудженої до позбавлення волі, і $€$ визначальною під час створення основних джерел національного законодавства в частині визначення основних засад поводження з в'язнями, прав та обов'язків засуджених, управління пенітенціарними установами, ресоціалізації засуджених осіб, участі громадськості в цьому процесі та ін.

Окрім власне юридичних норм, до міжнародних стандартів у галузі прав людини належать певні принципи, які визнаються самостійним джерелом права у сфері прав людини [12, с. 105]. Міжнародні стандартипринципи поводження із засудженими до позбавлення волі, що містяться у міжнародно-правових документах, мають фундаментальний характер, грунтуючись на необхідності забезпечення прав засуджених, які є невід'ємними від загальних прав людини (право на життя та особисту недоторканість, на повагу людської гідності, свободу від будьякої дискримінації, свободу совісті, думок і віросповідання тощо). Значущість принципів, сформульованих у міжнародно-правових документах 3 прав людини для формування цілей $\mathrm{i}$ завдань національної політики $\mathrm{y}$ сфері виконання кримінальних покарань в цілому і поводження з засудженими до позбавлення волі, зокрема, визначається тим, що вони мають міждержавний (наднаціональний) характер, не залежать від ідеологічних та поточних кримінологічних чинників i, таким чином, $\epsilon$ надійним чітким орієнтиром для розвитку законодавства і правозастосовної діяльності у сфері забезпечення прав і свобод громадян, засуд- 
жених до кри-мінального покарання у вигляді позбавлення волі [10, с. 24]. Міжнародні стандартирекомендації являють собою положення, які сформульовані у відповідних документах, що не мають обов'язкової юридичної сили, але, незважаючи на це, визнаються усіма міжнародними організаціями, урядами і неурядовими організаціями та іншими суб'єктами забезпечення прав і свобод громадян, у тому числі й адміністраціями установ позбавлення волі. Стандарти-рекомендації не ставлять своєю метою нав'язати цим суб'єктам певну систему взірців поводження із засудженими особами, а лише пропонують напрямки створення загальновизнаних гуманних умов утримання осіб у місцях позбавлення волі та моделей поводження з ними, які б забезпечували належну повагу до людської гідності.

Як прийняті або схвалені відповідними міжнародними організаціями норми, принципи та рекомендації, міжнародно-правові стандарти у сфері забезпечення захисту прав засуджених визначають:

- порядок i умови ізоляції осіб, які за рішенням національного суду або компетентного національного державного органу позбавлені волі;

- порядок і умови реалізації процесу відбування покарання особами, засудженими національним судом до позбавлення волі;

- гарантії і процедури захисту ïx прав, свобод і законних інтересів на національному рівні або $\mathrm{y}$ спеціально для цієї мети створених міжнародних органах; вимоги щодо підбору, підготовки, навчання та діяльності персоналу органів та установ, призначених для примусової ізоляції цих осіб та гарантій їх правового та соціального захисту;

- вимоги до інших фахівців, які не відносяться до персоналу цих органів та установ, але залучаються для забезпечення їх діяльності [13, c. 4].

До основних функцій міжнародних стандартів у галузі прав людини, що спрямовані на забезпечення прав і свобод громадян, засуджених до позбавлення волі, слід віднести:

- нормативну функцію (дія міжнародних стандартів як складової частини міжнародного права спрямована на встановлення й регулювання прав та свобод людини i громадянина на національному рівні);

- правозастосовну функцію (міжнародні стандарти мають забезпечувати ефективну імплементацію та реалізацію прав і свобод людини та громадянина);

- інформаційну функцію (міжнародні стандарти мають сприяти ефективному міжнародному інформаційному обміну у даній сфері);

- захисну та контрольну функції (міжнародні стандарти мають формувати та забезпечувати механізм захисту та охорони прав i свобод).

Даючи загальну оцінку нормам, що містяться у міжнародно-правових актах у даній галузі, слід зазначити низку важливих моментів. По-перше, у міжнародно-правових документах 3 прав людини не лише фіксуються ті чи інші параметри правового статусу осіб, що відбувають кримінальне покарання у вигляді позбавлення волі, але й розглядаються питання виправлення і соціального переви- 
ховання, утримування засуджених, управління установами пенітенціарної системи та ін., тобто розглядається весь комплекс заходів з організації виконання покарання та діяльності виправних установ. Подруге, у цих документах основний акцент робиться саме на регулювання правил виконання кримінального покарання у вигляді позбавлення волі, оскільки дане покарання спричиняє якісну зміну правового статусу засуджених в бік його звуження й безпосередньо пов'язане 3 практикою обмеження їх прав і свобод в установах пенітенціарної системи. По-третє, у міжнародно-правових актах основний наголос робиться на проголошення захисту прав засуджених та регламентацію гарантій їх здійснення, що сприяє гуманізації практики поводження із засудженими та процесу виконання покарання, тоді як закріплення правообмежень засуджених до позбавлення волі та безпосередніх обов'язків суб'єктів забезпечення їх прав передбачається на рівні національного законодавства. По-четверте, аналіз міжнародно-правових документів у галузі прав людини дозволяє зробити висновок про те, що вони в багатьох положеннях збігаються один з одним, що, на думку експертів, дає можливість надати їм більшого змісту шляхом перехресного посилання, тобто використовувати докладну статтю в одному документі як тлумачення більш загальної статті в іншому [14, с. 43].

Висновки. Отже, міжнародні стандарти поводження із засудженими до позбавлення волі складають прийняті на міжнародному рівні норми, принципи і рекомендації, що у своїй сукупності створюють єдиний міжнародно-правовий інститут захисту прав громадян, засуджених до позбавлення волі, і $€$ визначальними під час створення основних джерел національного законодавства в частині визначення основних засад поводження з в'язнями, прав та обов'язків засуджених до позбавлення волі, управління пенітенціарними установами, ресоціалізації засуджених осіб, участі громадськості в цьому процесі та ін. Специфічними ознаками міжнародних стандартів у галузі прав людини щодо забезпечення прав громадян, засуджених до позбавлення волі, є: фіксованість, модельність, універсальність, змістова динамічність, загальнодемократичність вимог та ін. До основних функцій міжнародних стандартів у галузі прав людини, що спрямовані на забезпечення прав і свобод громадян, засуджених до позбавлення волі, віднесено: нормативну, правозастосовну, інформаційну, захисну та контрольну функції.

\section{Список використаних джерел}

1. Права человека: международное право и национальное законодательство / под ред. проф. В. В. Филлипова. Вильнюс : ЕГУ, 2011. 338 с.

2. Встановлення міжнародних стандартів у сфері прав людини : Резолюція Генеральної Асамблеї ООН від 4 грудня 1986 р., № 41/120 / Офіційний веб-сайт ООН. URL: http://www.un.org/ru/ga/41/docs/41res.shtml (дата звернення: 11. 09.2020).

3. Рабінович П. М. Міжнародні стандарти прав людини: властивості, загальне поняття, класифікація. Вісник Нац. акад. правових наук України. 2016. № 1 (84). С. 1929. 
4. Раданович Н. Європейські стандарти прав людини: поняття, структура, джерела формування. Проблеми державотворення та захисту прав людини в Україні: матер. ХІІІ регіон. наук.-практ. конф. (8-9 лютого 2007 р.). Львів : Юр. фак. Львівського нац. ун-ту ім. І. Франка, 2007. С. 69-71.

5. Гончаров В. В. Офіційне тлумачення юридичних норм як засіб встановлення і трансформації їх змісту : автореф. дис. на здобуття наук. ступеня канд. юрид. наук. Нац. ун-т «Львівська політехніка». Львів, 2012. 18 с.

6. Голубок С.А. Международно-правовые стандарты права на судебную защиту. Правоведение. 2007. № 1. С.112-124.

7. Оганесян С. М. Понятие международных стандартов прав человека. Международное публичное и частное право. 2008. № 2. С. 18-21.

8. Тиунов О.И. Международно-правовые стандарты как фактор глобализации правового пространства. Московский юридический форум «Глобализация, государство, право, ХХІ век». Москва : Городец-издат., 2004. С. 156-166.

9. Ульяшина Л. Международно-правовые стандарты в области прав человека и их реализация: теория и практика применения. Вильнюс: ЕГУ, 2013. 402 с.

10. Міжнародні стандарти, принципи і рекомендації в галузі виконання покарань та діяльності органів і установ виконання покарань: методичні рекомендації / уклад. О. В. Романюк, В. О. Човган. Біла Церква, 2016. 131 с.

11. Лисодєд О. В. Закріплення міжнародних та європейських стандартів поводження із засудженими у кримінально-виконавчому законодавстві України (на прикладі Закону України від 8 квітня 2014 р. № 1186-VII). Питання боротьби зі злочинністю : зб. наук. пращь. 2015. Вип. 30. С. 64-76.

12. Теорія держави і права. Академічний курс : підручник / С. В. Бобровник ; за ред. О. В. Зайчука, Н. М. Оніщенко. 2-ге вид., переробл. і допов. Київ, 2008. 688 с.

13. Іваньков А. І. Міжнародно-правові стандарти у сфері забезпечення захисту прав засуджених до позбавлення волі : автореф. дис. на здобуття наук. ступеня канд. юрид. наук. Харк. нац. ун-т внутр. справ, 2016. 16 с.

14. Уткин В. А. Международные стандарты обращения с заключенными и проблемы их реализации: учебное пособие. Томск : Изд-во НТЛ, 1998. 88 с.

\section{References}

Rabinovich, P. M. (2016). Mizhnarodni standarti prav lyudini: vlastivosti, zagalne ponyattya, klasifikaciya. Visnik Nac. akad. pravovih nauk Ukrayini, 1 (84), 19-29 [in Ukrainian].

Goncharov, V. V. (2012). Oficijne tlumachennya yuridichnih norm yak zasib vstanovlennya i transformaciyi yih zmistu. (Avtoref. dis. na zdobuttya nauk. stupenya kand. yurid. nauk). Nac. un-t «Lvivska politehnika». Lviv [in Ukrainian].

Golubok, S. A. (2007). Mezhdunarodno-pravovye standarty prava na sudebnuyu zashitu. Pravovedenie, 1, 112-124.

Oganesyan, S. M. (2008). Ponyatie mezhdunarodnyh standartov prav cheloveka. Mezhdunarodnoe publichnoe i chastnoe pravo, 2, 18-21.

Tiunov, 0. I. (2004). Mezhdunarodno-pravovye standarty kak faktor globalizacii pravovogo prostranstva. Moskovskij yuridicheskij forum «Globalizaciya, gosudarstvo, pravo, XXI vek». Moskva: Gorodec-izdat., 156-166 [in Russian].

Ulyashina, L. (2013). Mezhdunarodno-pravovye standarty v oblasti prav cheloveka i ih realizaciya: teoriya i praktika primeneniya. Vilnyus: EGU [in Russian].

Lisodyed, O. V. (2015). Zakriplennya mizhnarodnih ta yevropejskih standartiv povodzhennya iz zasudzhenimi u kriminalno-vikonavchomu zakonodavstvi Ukrayini (na 
prikladi Zakonu Ukrayini vid 8 kvitnya 2014 r. № 1186-VII). Pitannya borotbi zi zlochinnistyu: zb. nauk. prac, 30, 64-76 [in Ukrainian].

Ivankov, A. I. (2016). Mizhnarodno-pravovi standarti u sferi zabezpechennya zahistu prav zasudzhenih do pozbavlennya voli. (Avtoref. dis. na zdobuttya nauk. stupenya kand. yurid. nauk). Hark. nac. un-t vnutr. sprav [in Ukrainian].

Utkin, V. A. (1998). Mezhdunarodnye standarty obrasheniya s zaklyuchennymi $i$ problemy ih realizacii. Tomsk: Izd-vo NTL [in Russian].

O. Pochanska, Doctor in Law, Assistant professor of the Department of Legal Support of Economic Activity of the Faculty 6 of Kharkiv National University of Internal Affairs

ORCID: 0000-0003-3953-8660

\section{Concept, content and functions of modern \\ international legal standards in the field of human rights of citizens sentenced to imprisonment}

The content of the concept of international legal standards in the field of is determined. It is emphasized that the key problem of the process of improving the rights and freedoms of citizens sentenced to imprisonment in Ukraine is the adaptation of national legislation (and, in particular, its administrative and legal component, which was and remains one of the most important factors in ensuring proper public relations). in this area) to modern international standards of treatment of convicts, which are an integral part of universally recognized world standards in the field of human rights. It is noted that the dynamics of international legal standards in the field of human rights, as well as the development of processes of reforming the penitentiary system of Ukraine and adaptation of national legislation to European and world standards in the context of Ukraine's European integration imprisonment. The main modern scientific approaches to determining the specific features of international standards of treatment of convicts are analyzed. The main functions of modern international legal standards in the field of ensuring the rights of citizens sentenced to imprisonment are highlighted, their content is characterized. The main functions of international human rights standards aimed at ensuring the rights and freedoms of citizens sentenced to imprisonment include: regulatory, law enforcement, information, protection and control functions.

Keywords: international legal standards of human rights; international standards for the treatment of convicts; sentenced to imprisonment. 